\title{
Data on Children Involved and the Social Costs Related to the Phenomenon of Maltreatment and Ill-Treatment towards Children in Italy
}

\author{
Giulia Savarese*, Luna Carpinelli, Rosa Angela Villani, Daniela D’Elia, Monica Romei \\ Department of Medicine and Surgery, University of Salerno, Salerno, Italy \\ Email: *gsavarese@unisa.it
}

How to cite this paper: Savarese, G., Carpinelli, L., Villani, R. A., D’Elia, D., \& Romei, M. (2020). Data on Children Involved and the Social Costs Related to the Phenomenon of Maltreatment and Ill-Treatment towards Children in Italy. Open Journal of Social Sciences, 8, 1-6.

https://doi.org/10.4236/jss.2020.83001

Received: January 3, 2020

Accepted: March 1, 2020

Published: March 4, 2020

Copyright $\odot 2020$ by author(s) and Scientific Research Publishing Inc. This work is licensed under the Creative Commons Attribution International License (CC BY 4.0).

http://creativecommons.org/licenses/by/4.0/

\begin{abstract}
This short paper refers to the social cost of child maltreatment in Italy. The cost of child violence is about 13.056 billion Euros per year, equivalent to $0.84 \%$ of National GDP. Direct costs amount to 338.6 million Euros, while indirect costs amount to 12.7 billion Euros. The new cases of maltreatment cost 910 million Euros each year. The paper discusses the data on cases of child violence and the related social costs in Italy, comparing its with International ones.
\end{abstract}

\section{Keywords \\ Child Violence, Social Cost, Italy}

The first survey on the epidemiological dimension of child maltreatment in Italy was conducted by Terre des Hommes (International Federation-TDHIF), mandated by the Authority Guarantor for Childhood and Adolescence, and in collaboration with Italian Coordination of Public and Private Services against Child Abuse (CISMAI) (Autorità Garante per l'Infanzia e l'Adolescenza CISMAI Terre des Hommes, 2016). It receives the support of the National Association of Italian Municipalities (ANCI) and the Italian National Institute of Statistics (ISTAT, 2015) and it was the first to quantify the phenomenon in Italy, highlighting the startling number and age range of underage victims. About 100,000 children, in fact, were found to be in the charge of social services because they were victims of a form of maltreatment (200 out of 1000 children are followed by Social Health Services, because of the mistreatment suffered from family, peers, supervisors, etc.), the most frequent of which was the material and affective neglect often hidden by domestic walls and therefore very complex to intercept and 
recognize.

According to this national survey, the number of children treated by Social Services in Italy is precisely 91,000 . Teenage girls and foreign teenagers are the two most affected categories.

The survey covered 2.4 million children resident in Italy (25\% of the underage Italian population) and represents the first and only statistically significant experience of its kind ever made in Italy, a timely and updated photograph of the research on child abuse. The first object of investigation was the total number of minors that were followed in Italy by the Social Services of Municipalities. The final figure shows that 47.7 minors out of 1000 are followed by social services. The number of Italian children and young people who are in a state of need and for whom an intervention by social services has been activated is 457,453 . In absolute value, there are 234,904 male minors in charge of social services in Italy and 200,048 females.

The prevalence of minors in charge of social services grows with increasing age. It increases, in fact, from 29 out of 1000 children up to 3 years old, to 54 between 11 and 17 years old. In percentages, pre-teens and teenagers to load social services are $42.1 \%$, amongst which $28.2 \%$ are in primary school, $11.2 \%$ are in the range of $4-5$ years and $11.8 \%$ are in early childhood (CISMAI \& Terre des Hommes, 2013).

These results, which highlight the work of Social Services, especially when children are already grown adults (grown up), would seem to confirm what has long been known in Italy, namely that it has poor development of Social-Health Services for the early prevention of child victims of maltreatment, as noted also from the Global Status of the WHO (2014).

Regarding the minors taken to the Italian Social Health Assistance in Italy:

$47.1 \%$ of them were exposed to material neglect and/or affective;

$19.4 \%$ of them were exposed to assisted violence;

$13.7 \%$ of them were exposed to psychological maltreatment;

$8.4 \%$ of them were in treatment condition (lack of care/hyper-care);

$6.9 \%$ of them were exposed to physical abuse;

$4.2 \%$ of them were exposed to sexual abuse;

$1.2 \%$ of them were exposed to a form of undefined violence (CISMAI \& Terre des Hommes, 2013).

Comparing the Italian data with that of foreign countries for every $1000 \mathrm{mi}-$ nors, the weight of maltreated minors is as follows (WHO, 2014):

Australia 6.8\%;

Canada 9.7\%;

England $11.2 \%$;

Italy $9.5 \%$;

The United States 12.1\%;

Therefore the Italian data is in line with the other countries analyzed.

With respect to intervention, the CISMAI \& Terre des Hommes (2013) re- 
search showed the following:

$38.4 \%$ of children have seen of forms of aid and direct support from Social Service professionals;

$27.9 \%$ receive an intervention of economic assistance to the family unit;

$19.3 \%$ of abused children are removed from the family home and placed in a youth residence;

$17.9 \%$ of them continue to be followed within their own family home with interventions of home educational assistance;

$14.4 \%$ are protected through a family trust;

$10.2 \%$ are supported inside a semi-residential day centre;

$7.6 \%$ do not receive any kind of intervention.

On average, each abused minor receives at least two types of protection and protection services.

A very interesting survey on the topic was developed by Cesvi (2018), "Regional index on child maltreatment in Italy", which constitutes an innovative tool to better understand what is being done and what must be done to prevent and combat all childhood mistreatment. The study made it possible to create a synthetic regional index on maltreatment in Italy that measures the vulnerability of minors with respect to the protection capabilities of the contexts in which children live, combining a regional indicator of risk factors and a policy indicator and an indicator of the prevention and contrast services. This is a phenomenon that is still unknown in its true dimension: the Social Services of the Italian municipalities follow almost 100,000 children every year (about 9.5 minors for every 1000 residents).

The WHO (2013) estimates that for every known case there are at least nine submerged cases that will never be followed or treated. If we project this data on adults today the figure of 9.5 abused children/adults assisted by Social Services of the Municipalities out of 1000 minors and that of nine cases submerged for each case known, the result is a total of nearly six million abused between adults and children (5.7 million), or slightly less than $10 \%$ of the national population. Taking action on the mistreatment of children/adults means, therefore, intervening and even preventing all other forms of violence that plague our society: violence between adults, violence against women, violence against children, widespread crime and social and economic malaise.

Violence against children is a worrying and widespread phenomenon worldwide. In 2015, about three out of four children (1.7 billion minors) experienced some form of interpersonal violence. In particular, 1.3 billion children have been subjected to some form of corporal punishment and 261 million schoolchildren experienced violence from their peers, while 100,000 children were victims of murder. Given such dramatic data, it should be pointed out that violence against children is an underestimated phenomenon, as calculated by the WHO itself. The most widespread form of violence is family violence; boys and girls are in fact abused especially in this environment which should more than anything en- 
sure their safety and protection. Between $60 \%$ and $70 \%$ of children/adolescents between two and fourteen years of age have experience of emotional violence by their caregivers, and in industrialized countries approximately $58 \%$ of children/adolescents suffered some form of violent discipline at home (Know Violence in Childhood: Global Report, 2017).

The violence does not spare even the little ones. According to data from 30 countries, six out of ten children between 12 and 23 months old are subject to violent discipline and at least half of these are exposed to verbal abuse. Countering maltreatment in the family can also be particularly complicated, since the family sphere, in many cultures and societies, is still considered a private sphere and as such it is difficult not only to estimate the phenomenon, but also to intervene adequately. In Europe, as in the rest of the world, cases of mistreatment and neglect are widespread and potentially underestimated (UNICEF, 2017a, 2017b).

According to the WHO-Regional Office for Europe $(2013,2016)$, in Europe about 18 million children are victims of sexual abuse, 44 million are victims of physical abuse and 55 million of mental abuse. It is estimated, moreover, that in Europe at least 850 children/adolescents under 15 years of age die as a result of mistreatment, although not all mistreatment has fatal consequences. The most recent report by Terres des Hommes (2017) in "The condition of girls in the world" highlights how domestic violence is the most significant cause. Most of the crimes are against children: in 2016 in Italy, in fact, there were 1618 child victims of maltreatment in the family (of which $51 \%$ were girls), with an increase of $12 \%$ compared to the previous year. The number of child/young victims of violent discipline was also increased $(+23 \%)$, while the sexual abuse of children under 14 years of age has slightly decreased $(-11 \%)$, with $80 \%$ of victims being girls. Also, they continue to play an important role in the Italian context, as some of the stereotypes that usually normalize the use of violence, though the subordinate position of women and children within families can, in turn, justify violent behavior in domestic environments WHO-Regional Office for Europe (2013, 2016).

As for the economic costs related to maltreatment, some estimates have been made that do not exclusively concern maltreatment within the family; however, the numbers are useful to understand how much it costs not to invest adequately in the prevention of violence against children in all its forms.

UNICEF (2016) estimates that for the USA the costs throughout the life course related to child maltreatment amount to about 124 billion dollars per year (the estimate includes health care, social services expenses, legal fees, lost productivity and earnings). Data of the Copenhagen Consensus Centre (Fearon \& Hoeffler, 2014) have instead calculated the total cost of violence against children/youths in the world in 3.7 billion dollars, a figure that is equivalent to $4.3 \%$ of global GDP. The estimate includes murders, abuses and sexual violence.

As far as non-fatal abuses (such as corporal punishment) are concerned, for 
Europe and Central Asia the cost is estimated at 173 billion dollars (equal to $3.16 \%$ of the GDP of the region considered), while sexual abuse costs equal 1.1 billion Dollars (Fearon \& Hoeffler, 2014).

Moreover, WHO $(2013,2016)$ shows that the economic costs related to violence against children amount to $£ 1.14$ billion each year in the UK and to 11 billion Euros in Germany.

Finally, with regards to Italy, a national survey conducted by CISMAI, Terre des Hommes and the Bocconi University in "Do Child Cuts Really Lead to Savings? Impact of Lack of Prevention for Violence against Children on Public Expenditure" (2013), brings to the attention of the public and institutions the direct and indirect costs that arise daily from the failure to prevent violence against children.

It has emerged that about $1 \%$ of our GDP is spent each year to meet the expenses resulting from violence against children, an element that is also essential for the definition of suitable prevention policies.

The study of CISMAI \& Terres des Hommes (2013) reported that the cost of child abuse is about 13.056 billion Euros per year, equivalent to $0.84 \%$ of GDP. Direct costs amount to 338.6 million Euros, while indirect costs amount to 12.7 billion Euros. For the new cases of maltreatment, the study continues and costs Italy 910 million Euros each year.

\section{Conflicts of Interest}

The authors declare no conflicts of interest regarding the publication of this paper.

\section{References}

Autorità Garante per l'Infanzia e l'Adolescenza CISMAI Terre des Hommes (2016). Indagine nazionale sul maltrattamento dei bambini e degli adolescenti in Italia. https://www.garanteinfanzia.org/news/maltrattamento-sui-bambini-italia-esce-da-oscu rantismo-dati

Cesvi (2018). Liberi tutti: indic eregionale sul maltrattamento all'infanzia in Italia. https://www.cesvi.org

CISMAI, \& Terre des Hommes (2013). Tagliare sui bambini è davvero un risparmio? Spesa pubblica: Impatto della mancata prevenzione della violenza sui bambini.

http://terredesHommes.it/comunicati/i-maltrattamenti-sui-bambini-costano-13-miliar di-di-euro-ogni-anno/

Fearon, J., \& Hoeffler, A. (2014). Benefits and Costs of the Conflict and Violence Targets for the Post-2015 Development Agenda. Conflict and Violence Assessment Paper, Copenhagen Consensus Center.

https://www.copenhagenconsensus.com/sites/default/files/conflict_assessment_-_hoeff ler_and_fearon_0.pdf

Terre des Hommes (2017). La condizionedellebambine e delleragazzenelmondo. https://terredesHommes.it/indifesa/InDifesaDossier_2017.pdf

ISTAT (2015). La violenza contro le donne dentro e fuori la famiglia. https://www.istat.it/it/files/2015/06/Violenze_contro_le_donne.pdf?title=Violenza+con 
tro+le+donne+-+05\%2Fgiu\%2F2015+-+Testo+integrale.pdf

Global Report (2017). Know Violence in Childhood, Ending Violence in Childhood. http://globalreport.knowviolenceinchildhood.org/

UNICEF (2016). Child Protection from Violence, Exploitation and Abuse, UNICEF, New York. https://www.UNICEF.org/protection/57929_58002.html

UNICEF (2017a). A Familiar Face: Violence in the Lives of Children and Adolescents, UNICEF, New York.

https://www.UNICEF.org/eapro/A_Familiar_Face_Violence_in_the_Lives_of_Childre $\underline{\text { n_and_Adolescents.pdf }}$

UNICEF (2017b). Children of Austerity. UNICEF, New York: Oxford University Press. https://www.UNICEF-irc.org/publications/pdf/Children_of_austerity.pdf

WHO-Regional Office for Europe (2013). European Report on Preventing Child Maltreatment.

http://www.euro.who.int/_data/assets/pdf_file/0019/217018/European-report-on-prev enting-child-maltreatment.pdf

WHO-Regional Office for Europe (2016). Measuring and Monitoring National Prevalence of Child Maltreatment: A Practical Handbook.

http://www.euro.who.int/_data/assets/pdf_file/0003/317505/Measuring-monitoring-n ational-prevalence-child-maltreatment-practical-handbook.pdf

WHO (2014). Investing in Children: The European Child Maltreatment Prevention Action Plan 2015-2020.

http://www.euro.who.int/_data/assets/pdf_file/0011/282863/Investing-in-children-Eu ropean-child-maltreatment 